[Case Report]

\title{
A Case Report of Intralobar Pulmonary Sequestration De- tected by Lung Cancer Screening with Low-Dose Spiral CT
}

\author{
Hisamitsu Omori' ${ }^{1}$, Keiko SATA ${ }^{1}$, Ryuichi SaIToh ${ }^{1}$, Shuichi Mihara', \\ Tohru Marubayashi', Akiko Narimatsu' ${ }^{2}$, Kohichi KaWANaKa ${ }^{3}$ and \\ Seiji ToMiguchI ${ }^{4}$ \\ ' Japanese Red Cross Kumamoto Health Care Center, Kumamoto 861-8528, Japan \\ ${ }^{2}$ Narimatsu Clinic, Kumamoto 861-4146, Japan \\ ${ }^{3}$ Department of Diagnostic Radiology, Grauate School of Medical Sciences, Kumamoto University, \\ Kumamoto 860-8556, Japan \\ ${ }^{4}$ School of Health Sciences, Kumamoto University, Kumamoto 860-8556, Japan
}

Abstract: A 52-year-old man underwent lung cancer screening with low-dose spiral computed tomography(CT) in a medical check-up at the Japanese Red Cross Kumamoto Health Care Center. He was asymptomatic. Chest x-ray on a medical check-up showed no abnormal shadows. CT scans revealed a nodule in the right lower lung, suggestive of its connection to the descending thoracic aorta. A diagnosis of pulmonary sequestration was considered. He was transferred to Kumamoto University Hospital for further examination. Contrast enhanced multidetector CT images demonstrated that a nodule in the right lower lobe and an anomalous artery ran from the descending thoracic aorta, flowed through the right lower lobe and returned to the right inferior pulmonary vein. Intralobar pulmonary sequestration was confirmed by contrast enhanced multidetector CT. We report this case of asymptomatic intralobar pulmonary sequestration diagnosed using contrast enhanced multidetector CT.

Key words : intralobar pulmonary sequestration, screening, multidetector CT.

(Received 3 May 2007, accepted 15 May 2007)

\section{Introduction}

Pulmonary sequestration is a rare congenital pulmonary disorder defined as an area of dysplastic and nonfunctioning pulmonary tissue with an anomalous systemic blood supply [1]. Pulmonary sequestration usually presents during childhood, but up to half present after the age of 20 [2]. Signs of recurrent infection, such as fever and productive cough, are 
common onset that usually occur before the age of 40 [3].

Here we report a case of asymptomatic intralobar pulmonary sequestration that presented during adulthood. He was thought to have pulmonary sequestration by lung cancer screening with low-dose spiral CT in medical check-up and was successfully diagnosed using contrast enhanced multidetector CT.

\section{Case Report}

A 52-year-old man underwent low dose spiral CT in a medical check-up at the Japanese Red Cross Kumamoto Health Care Center. He was asymptomatic. His blood chemistry and serology were normal. Chest x-ray in the medical check-up showed no abnormal shadows. CT scan (Fig. 1) demonstrated a nodule (16 $\mathrm{mm}$ in size) connected to the descending thoracic aorta in the right lower lobe(S10 region), suggesting the presence of a pulmonary sequestration.
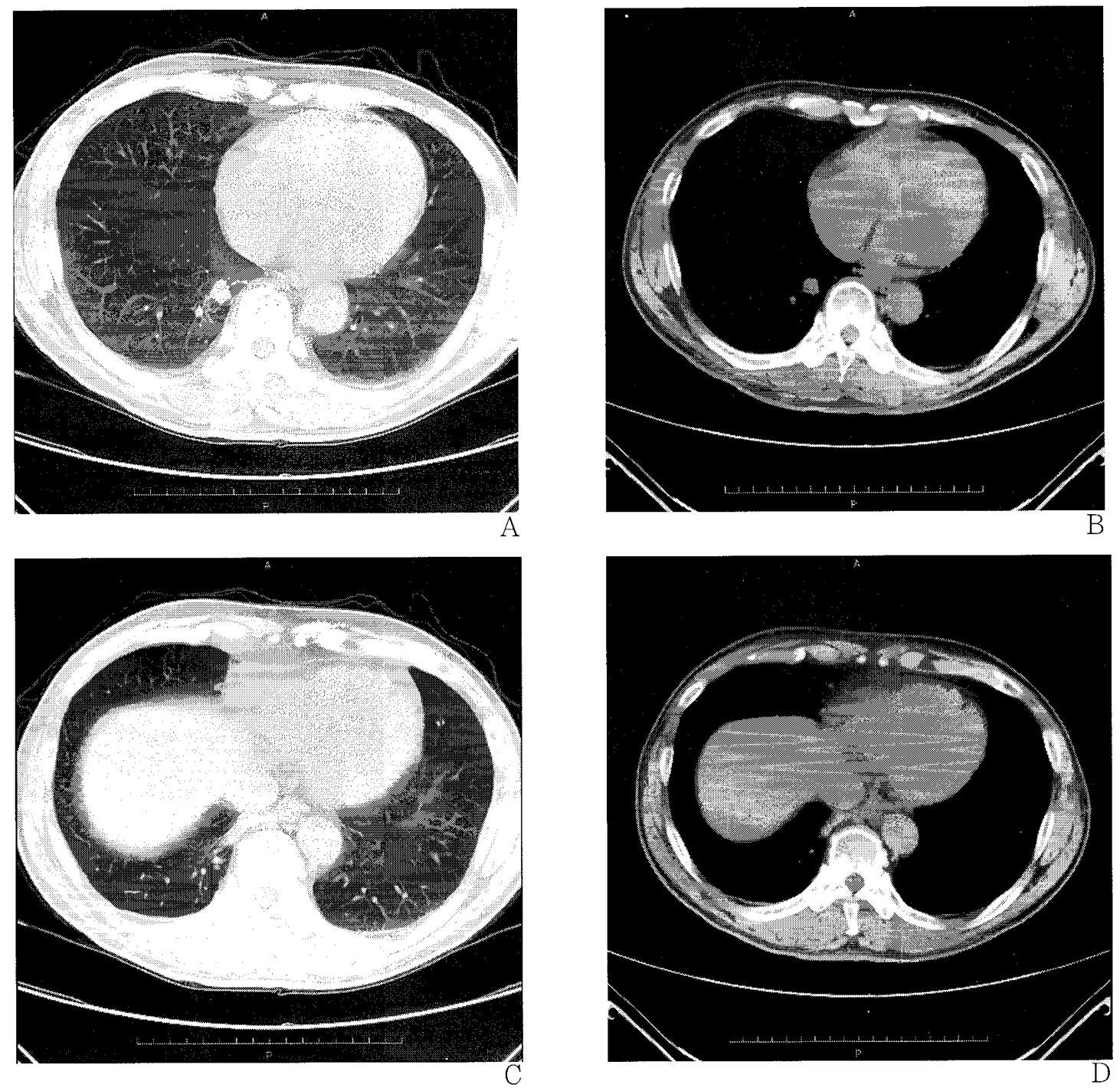

Fig. 1. (A) and (B) Chest CT scan show the nodule in the right lower lung. (C) and (D) Lower slice of CT scan suggests the connection to the descending thoracic aorta. 
He was transferred to Kumamoto University Hospital for further examination. Contrast enhanced multidetector CT axial images (Fig. 2) demonstrated a nodule in the right lower lobe and identified its anomalous arterial supply from the descending thoracic aorta. A diagnosis of intralobar pulmonary sequestration was considered. Contrast enhanced multidetector CT coronal images (Fig. 3) showed an aberrant artery that originated on the right side of the descending thoracic aorta, flowed through the right lower lobe and drained into the right inferior pulmonary vein. The nodule was found to have cystic legion (shown in Fig. 3). Intralobar pulmonary sequestration was confirmed by contrast enhanced multidetector CT.
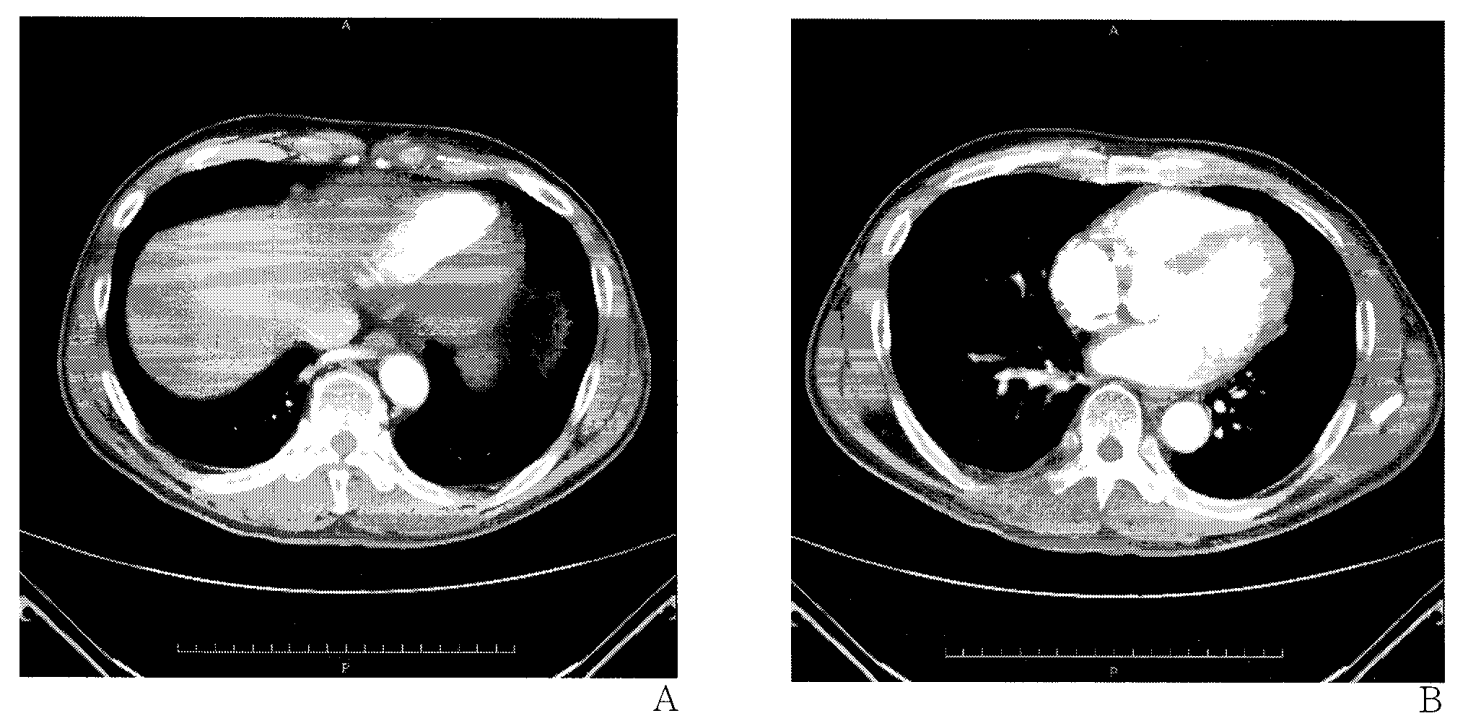

Fig. 2. (A) and (B) Contrast enhanced chest CT axial images show an abnormal blood vessel extending from the descending thoracic aorta to the right lower lung and draining into the right inferior pulmonary vein.
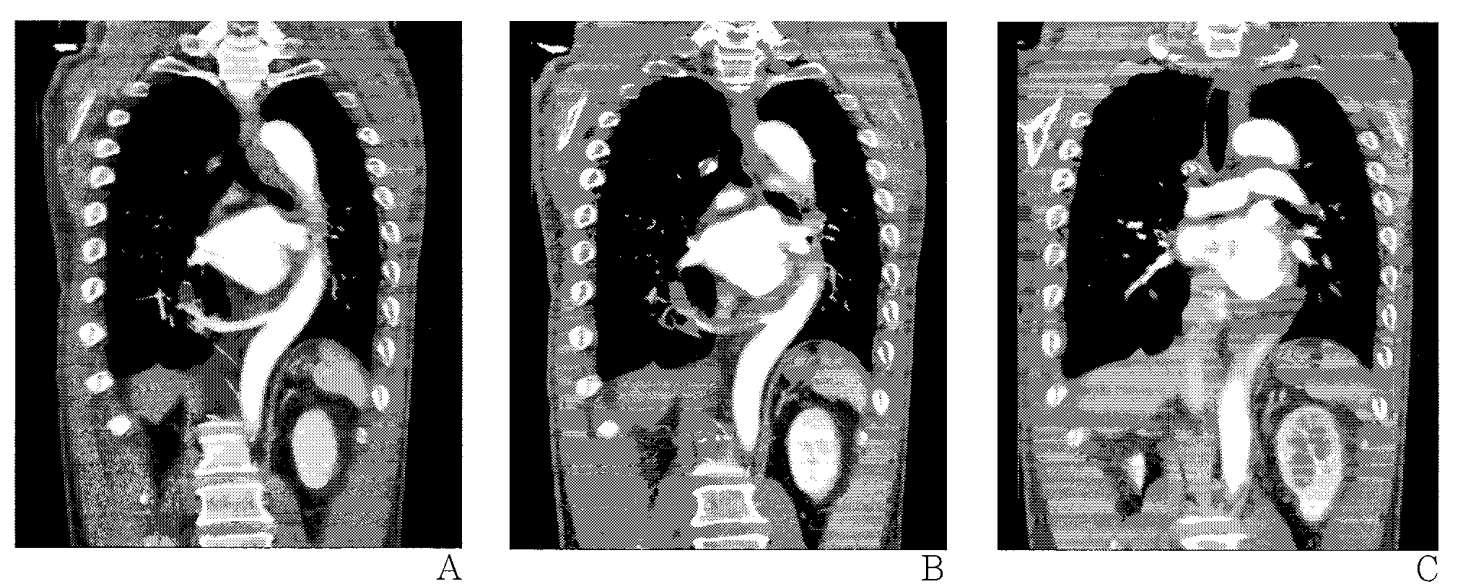

Fig. 3. (A), (B) and (C) Contrast enhanced multidetector CT coronal images show an aberrant artery that originated on the right side of the descending thoracic aorta, flowed through the right lower lobe, and drained into the right inferior pulmonary vein. 


\section{Discussion}

Pulmonary sequestration is a rare congenital lung malformation characterized by an abnormal segment of bronchopulmonary tissue supplied by an anomalous systemic artery. The term "sequestration" was first used in the medical literature by Pryce in 1946 [4]. Pulmonary sequestration is a rare congenital abnormality, representing $0.15-6 \%$ of all pulmonary malformations [5]. Intralobar sequestration is the common form of classic pulmonary sequestration. On the basis of a review of the literature by Felker et al [1], intralobar pulmonary sequestration accounts for approximately $75 \%$ of all sequestrations. A large majority of cases (98\%) occur in the lower lobes, usually from the descending thoracic aorta $(73 \%)[1]$.

This case is asymptomatic and was detected incidentally by lung cancer screening with low-dose spiral CT. The vast majority of patients with intralobar pulmonary sequestration are asymptomatic and carry the abnormality for years, only to be diagnosed during a routine chest radiograph for unrelated symptoms [6]. Most patients present with cough, sputum production and recurrent pneumonia. Rarely, a case with tuberculosis confined to the sequestration was reported [7]. Over 50\% are symptomatic by the age of 20 [4].

Several reports demonstrated that spiral CT scanning is useful in the diagnosis and assessment of pulmonary sequestration $[2,8-10]$. In this report, contrast enhanced multidetector CT successfully delineated the pulmonary abnormal tissue, the arterial supply and venous drainage.

The standard treatment for symptomatic sequestration is surgery, but the timing of surgery is somewhat controversial [6]. Most experts advocate that asymptomatic patients discovered to have an intralobar pulmonary sequestration during screening for a concomitant illness be referred for surgery, because there are reported cases of death in adulthood due to massive hemoptysis from intralobar pulmonary sequestration diagnosed in childhood [11]. A less common strategy of close monitoring for symptoms and referral to surgery, if symptoms develop, is occasionally advocated [12]. This case is now under monitoring for symptoms. When symptoms develop, however, patients should be referred for definitive surgery.

In summary, we report a case of asymptomatic intrapulmonary sequestration which was detected by lung cancer screening with low-dose spiral CT and successfully diagnosed using contrast enhanced multidetector CT.

\section{References}

1. Felker RE \& Tonkin ILD(1990): Imaging of pulmonary sequestration. AJR 154: 241-249

2. Petersen G, Martin U, Singhal A \& Griner GJ (2003): Intralobar sequestration in the middle-aged and elderly adults: recognition and radiographic evaluation. J Thorac Cardiovasc Surg 126: $2086-2090$

3. Savic B, Birtel FJ, Tholen W et al(1979): Lung sequestration: report of seven cases and review of 540 published cases. Thorax 34: 96-101

4. Pryce DM(1946): Lower accessory pulmonary artery with intralobar sequestration of lung: report of seven cases. J Pathol Bacteriol 58: 457-467 
5. Corbett JH \& Humphrey GME(2004): Pulmonary sequestration. Paediatr Respir Rev 5(1): $59-$ 68

6. Cooke CR (2006): Bronchopulmonary sequestration. Respir Care 51: 661-664

7. Yatera K, Izumi M, Imai M, Ikegami T, Miyazaki N \& Kido M (2005): Intralobar sequestration with tuberculous infection confined to the sequestrated lung. Respirology 10: 685-688

8. Kang M, Khandelwan N, Ojili V, Rao KL \& Rana SS (2006): Multidetector CT angiography in pulmonary sequestration. J Comput Assist Tomogr 30: 926-932

9. Coulier B, Mailleux P, Van Cutsem O, Bachez P, Mairesse M \& Ledent C(1999): Diagnosis of intralobar sequestration using helical computed tomography angiography: apropos of 3 patients. JBR-BTR 82(1): 6-10

10. Franco J, Aliaga R, Domingo ML \& Plaza P(1998): Diagnosis of pulmonary sequestration by spiral CT angiography. Thorax 53: 1089-1092

11. Mason RJ, Broaddus C, Murray JF \& Nadel JA(2005): Murray \& Nadel's Textbook of Respiratory Medicine, 4 th ed. Philadelphia Saunders 2832pp

12. Laberge JM, Bratu I \& Flageole H(2004): The management of asymptomatic congenital lung malformations. Paediatr Respir Rev 5 Suppl A: S305-S312

低線量ラセンCTによる肺癌検診にて発見された肺葉内肺分画症の一例

大森 久光 ${ }^{1}$, 佐多 桂子 ${ }^{1}$, 西東 龍一 $^{1}$, 三原 修一 ${ }^{1}$, 丸林 徹 ${ }^{1}$, 成松 明子 ${ }^{2}$, 河中 功一 ${ }^{3}$, 冨口 静二 4

'日本赤十字社 熊本健康管理センター

${ }^{2}$ 成松クリニック

3 熊本大学 医学薬学研究部 放射線診断科

4 熊本大学医学部 保健学科

要旨：低線量ラセンCTによる肺癌検診にて発見された肺葉内肺分画症の一例を報告する。症例は 52 歳男性. 自覚症状はなく胸部X線検查にて明らかな異常陰影は指摘できなかった. CT にて右下葉S10 に結節状の異常陰影を認めた。この陰影の内部には胸部下行大動脈より分 岐する異常血管の存在が疑われ，肺分画症が示唆された。造影multidetector CTにて胸部 下行大動脈より分岐する異常動脈の存在が確認され, 右下葉の異常陰影に流入後, 右下肺静 脈に還流しており,肺葉内肺分画症と診断された。胸部造影multidetector CT検査が診断 に有用であった。

キーワード：肺葉内肺分画症, スクリーニング, multidetector CT.

J UOEH（産業医大誌） 29 (3) : 259-263 (2007) 